Research

\title{
Plasma lipid profiles and risk of cardiovascular disease in occupational lead exposure in Abeokuta, Nigeria Oladipo Ademuyiwa ${ }^{* 1}$, Regina Ngozi Ugbaja ${ }^{1}$, Florence Idumebor ${ }^{1}$ and Olugbenga Adebawo ${ }^{2}$
}

\author{
Address: ${ }^{1}$ Department of Biochemistry, University of Agriculture, Abeokuta, Nigeria and ${ }^{2}$ Department of Biochemistry, Olabisi Onabanjo \\ University, Ikenne, Nigeria \\ Email: Oladipo Ademuyiwa* - adelad2@yahoo.com; Regina Ngozi Ugbaja - regiugbaja@yahoo.com; \\ Florence Idumebor - florence_idumebor@yahoo.com; Olugbenga Adebawo - ooadebawo@yahoo.co.uk \\ * Corresponding author
}

Published: 28 September 2005

Lipids in Health and Disease 2005, 4:19 doi:10.1186/1476-5IIX-4-19

This article is available from: http://www.lipidworld.com/content/4/1/19

(C) 2005 Ademuyiwa et al; licensee BioMed Central Ltd.

This is an Open Access article distributed under the terms of the Creative Commons Attribution License (http://creativecommons.org/licenses/by/2.0), which permits unrestricted use, distribution, and reproduction in any medium, provided the original work is properly cited.
Received: 31 August 2005

Accepted: 28 September 2005

\begin{abstract}
In order to investigate the effects of lead exposure on risk of cardiovascular disease during occupational exposure to this metal, plasma cholesterol and its fractions as high-density liporotein $(\mathrm{HDL})$, low-density liporotein (LDL) and triglyceride were determined in various artisans in Abeokuta, Nigeria who have been shown to be occupationally exposed to lead and these were related to blood lead levels. Increased risk of cardiovascular disease was observed in the artisans. Total cholesterol in the artisans was between I.5 and 2.0 times higher in the artisans than that present in controls while LDL cholesterol was between 1.6 and 2.4 times higher in the artisans when compared with control subjects $[\mathrm{P}<0.00 \mathrm{I}]$. HDL cholesterol and triglyceride levels were not affected [ $>$ 0.05]. A significant positive correlation was observed between blood lead and total cholesterol on one hand $\left[r=0.372 ; p=3.0 \times 10^{-5}\right]$ and blood lead and LDL cholesterol on the other hand $[r=0.283 ; p=0.001]$. LDL/HDL cholesterol ratio was also higher in the artisans when compared with control. Blood pressure (systolic and diastolic) and other anthropometric parameters were not significantly different between the artisans and the control subjects [ $>>0.05]$. Results suggest that lead exposure increases cholesterol synthesis and transport to peripheral tissues whereas reverse cholesterol transport to the liver is not affected.
\end{abstract}

\section{Introduction}

Studies in both humans and animals indicate that lipid metabolism is altered in chronic lead exposure [1-6]. The pathophysiological mechanisms involved in this leadinduced alterations are not completely understood. Lead has been shown to accelerate lipid oxidation in the presence of hemoglobin or $\mathrm{Fe}^{2+}[7,8]$. Lead was also shown to enhance $\mathrm{Fe}^{2+}$-initiated lipid oxidation in liposomes, erythrocytes, microsomal fractions and rat brain homogenates $[1,7,9]$. Altered fatty acid composition of erythrocyte membranes has also been demonstrated in chronic lead exposure $[5,10,11]$. It has also been demonstrated that lead exposure affects levels of galactolipid metabolic enzymes in the developing rat brain resulting in myelin defects [3]. All these observations are largely more suggestive than conclusive about lead-induced alterations in lipid metabolism.

Lead poisoning is presently becoming the most common disease of environmental origin and is increasing very 
rapidly in developing countries [12-16]. While lead exposure studies is a well-trodden subject in economically advanced countries [17-22], few published reports exist about lead poisoning and its associated effects in developing countries like Nigeria [12-14,16].

During the past years, numerous reports have appeared in the literature indicating that abnormal blood lipid levels like total cholesterol and other lipids and lipoproteins predispose individuals to atherosclerosis and cardiovascular diseases [23-27]. We have previously reported on chronic lead poisoning and its associated biochemical effects in auto-mechanics, petrol station attendants and some other artisans in Abeokuta, Nigeria [12-14,16]. To the best of our knowledge, data regarding the distribution of blood lipids and the risk of cardiovascular disease associated with this distribution in those who are occupationally exposed to lead in Nigeria, are lacking. In order to gain an insight into lead exposure and its effects on lipid profiles, we investigated the distribution of blood lipids in various artisans in Abeokuta, Nigeria, who have been shown to be occupationally exposed to lead.

\section{Subjects and methods Study population}

A total of 110 male subjects participated in the study. Control subjects were made up of staff and students of University of Agriculture, Abeokuta, Nigeria, while leadexposed subjects comprised of different artisans located in two mechanic workshops in the southern and northern parts of the city of Abeokuta, Nigeria. It is typical of mechanic workshops in Nigeria to find other groups of artisans located in these workshops in addition to the auto-mechanics, thereby complementing each other's services. In these workshops, there is always a preponderance of auto-mechanics. After explaining the objectives and the requirements of the study to them, a total of 92 artisans, including 50 auto-mechanics, consented to participate in the study. Seven male petrol station attendants from a petrol station in the southern part of the city were also included among the occupationally exposed subjects. Table 1 summarises the study population.

\section{Anthropometric measurements and body composition}

The weight of each subject was measured to the nearest $0.1 \mathrm{~kg}$ with a battery operated scale while the subjects were dressed in their underwear and height was measured to the nearest centimeter with the aid of a portable stadiometer. From these data, Body Mass Index (BMI), Body Surface Area (BSA), Body Fat Mass Index (BFMI), Fat Free Mass Index (FFMI), ), Lean Body Mass (LBM), Body Fat Mass (BFM), Total Body Water (TBW), Intracellular Fluid (IF) and Extracellular Fluid (EF), were calculated [28$30,35]$. Blood pressure was measured two times on the left arm in each subject in a supine position with a traditional
Table I: Study population

\begin{tabular}{lc}
\hline Subject & Number \\
\hline Control & 11 \\
Auto-mechanics & 50 \\
Auto-electricians & 8 \\
Battery chargers & 2 \\
Drivers & 2 \\
Painters (Vehicle) & 7 \\
Panel beaters & 15 \\
Petrol station attendants & 7 \\
Upholsterers & 4 \\
Spare parts/Oil sellers & 2 \\
Welders & 2 \\
\hline
\end{tabular}

sphygmomanometer (Cacosson Products, England) [31]. Each measurement was spaced twenty minutes apart and was usually performed before collection of blood samples. The average of the two measurements was used for all analyses.

\section{Blood analyses}

Venous blood samples were obtained between 8.00 a.m and 10.00 a.m from the subjects after an overnight fast. Aliquots of blood samples were separated for lead analysis and the remaining blood samples were centrifuged to separate plasma and red blood cells. Plasma concentrations of total cholesterol, LDL-cholesterol and triglycerides were determined with commercial kits (Randox Laboratories, Crumlin, England). HDL-cholesterol was determined in plasma with the same commercial kits for total cholesterol after very low density lipoproteins (VLDL) and low density lipoproteins (LDL) were precipitated with heparin- $\mathrm{MnCl}_{2}$ solution [32]. Blood lead analysis was performed using atomic absorption spectrophotometry. Details of this have been given elsewhere $[13,14]$.

\section{Statistical protocol}

Results are expressed as mean \pm S.D. One-way analysis of variance (ANOVA) followed by the least significant difference (LSD) test were used to analyse the results with $\mathrm{p}<$ 0.05 considered significant [33]. The relationships between blood lead levels and plasma lipids and the anthropometric parameters were also analysed using Pearson correlations [33].

\section{Results}

\section{Demographic and anthropometric characteristics}

The demographic and anthropometric characteristics of the subjects are depicted in Table 2. Their ages ranged between 18 and 66 years. The years of experience on the job for each group also shows a wide variation ranging from 0.7 to 53 in the auto-mechanics and 1.5 to 5 in the 
Table 2: Some demographic and anthropometric characteristics of the subjects. Values are mean \pm S.D.

\begin{tabular}{|c|c|c|c|c|c|c|c|c|c|c|c|}
\hline \multirow[b]{2}{*}{ Parameters } & \multicolumn{11}{|c|}{ Subjects } \\
\hline & Control & Auto-mechanics & $\begin{array}{l}\text { Auto- } \\
\text { electricians }\end{array}$ & Battery chargers & Drivers & $\begin{array}{l}\text { Painters } \\
\text { (Vehicle) }\end{array}$ & Panel beaters & $\begin{array}{l}\text { Petrol station } \\
\text { attendants }\end{array}$ & Upholsterers & $\begin{array}{l}\text { Spare parts/Oil } \\
\text { sellers }\end{array}$ & Welders \\
\hline Age (years) & $26.00 \pm 6.65$ & $28.02 \pm 10.72$ & $32.00 \pm 10.17$ & $27.00 \pm 7.07$ & $39.50 \pm 12.02$ & $34.00 \pm 19.56$ & $29.53 \pm 13.03$ & $28.71 \pm 3.99$ & $29.25 \pm 8.96$ & $30.50 \pm 0.70$ & $37.50 \pm 3.54$ \\
\hline $\begin{array}{l}\text { Job experience } \\
\text { (years) }\end{array}$ & - & $11.64 \pm 10.92$ & $13.25 \pm 11.18$ & $7.50 \pm 0.71$ & $4.00 \pm 2.83$ & $15.71 \pm 19.96$ & $12.47 \pm 10.45$ & $3.57 \pm 1.54$ & $12.38 \pm 11.46$ & $6.50 \pm 2.12$ & $25.50 \pm 0.71$ \\
\hline $\begin{array}{l}\text { Hours spent/day } \\
\text { in workshop }\end{array}$ & $8.64 \pm 0.92$ & $11.62 \pm 0.78$ & $11.25 \pm 1.16$ & $11.50 \pm 0.71$ & $10.00 \pm 0.00$ & $11.14 \pm 0.69$ & $11.20 \pm 0.68$ & $14.29 \pm 3.25$ & $11.25 \pm 1.50$ & $10.50 \pm 2.12$ & $11.50 \pm 0.71$ \\
\hline Height (m) & $1.69 \pm 0.05 a$ & $1.67 \pm 0.13 a$ & $1.72 \pm 0.05 a$ & $1.70 \pm 0.02 \mathrm{a}$ & $1.68 \pm 0.04 a$ & $1.73 \pm 0.08 \mathrm{a}$ & $1.72 \pm 0.03 a$ & $1.71 \pm 0.08 \mathrm{a}$ & $1.69 \pm 0.07 a$ & $1.68 \pm 0.02 \mathrm{a}$ & $1.73 \pm 0.04 a$ \\
\hline Weight (kg) & $60.64 \pm 8.10 a$ & $62.44 \pm 11.54 a$ & $62.38 \pm 7.89 a$ & $57.50 \pm 0.71 \mathrm{a}$ & $67.00 \pm 11.31 \mathrm{a}$ & $54.33 \pm 2.52 a$ & $63.71 \pm 10.16 a$ & $68.00 \pm 7.26 a$ & $58.25 \pm 11.62 a$ & $58.00 \pm 4.24 a$ & $67.50 \pm 14.85 a$ \\
\hline BMI $\left(\mathrm{kg} / \mathrm{m}^{2}\right)$ & $21.34 \pm 3.07 a$ & $21.78 \pm 3.76 a$ & $20.88 \pm 2.06 a$ & $20.02 \pm 0.25 a$ & $23.66 \pm 2.8 \mathrm{lb}$ & $18.15 \pm 1.72 a$ & $21.71 \pm 3.73 a$ & $23.49 \pm 3.39 b$ & $20.62 \pm 4.34 \mathrm{a}$ & $20.66 \pm 0.99 a$ & $24.84 \pm 0.90 b$ \\
\hline $\mathrm{BSA}\left(\mathrm{m}^{2}\right)$ & $1.69 \pm 0.1 \mathrm{la}$ & $1.71 \pm 0.14 a$ & $1.72 \pm 0.10 \mathrm{a}$ & $1.66 \pm 0.03 a$ & $1.76 \pm 0.16 a$ & $1.65 \pm 0.08 \mathrm{a}$ & $1.78 \pm 0.12 a$ & $1.79 \pm 0.10 \mathrm{a}$ & $1.64 \pm 0.20 \mathrm{a}$ & $1.41 \pm 0.29 b$ & $1.88 \pm 0.09 c$ \\
\hline BFMI $\left(\mathrm{kg} / \mathrm{m}^{2}\right)$ & $3.81 \pm 1.45 \mathrm{a}$ & $4.08 \pm 2.29 a$ & $3.24 \pm 1.19 a$ & $3.29 \pm 0.72 a$ & $5.17 \pm 1.92 \mathrm{a}$ & $1.81 \pm 0.91 \mathrm{a}$ & $8.57 \pm 4.39 c$ & $6.04 \pm 2.30 \mathrm{~b}$ & $10.28 \pm 8.24 d$ & $3.24 \pm 0.60 \mathrm{a}$ & $6.35 \pm 0.2 \mathrm{lb}$ \\
\hline FFMI $\left(\mathrm{kg} / \mathrm{m}^{2}\right)$ & $17.53 \pm 1.63 a$ & $17.44 \pm 3.64 a$ & $17.48 \pm 0.84 a$ & $16.73 \pm 0.47 a$ & $18.50 \pm 0.91 \mathrm{a}$ & $16.35 \pm 0.81 \mathrm{a}$ & $15.88 \pm 3.75 a$ & $17.44 \pm 1.08 \mathrm{a}$ & $10.34 \pm 12.45 b$ & $17.43 \pm 0.40 \mathrm{a}$ & $18.46 \pm 1.08 \mathrm{a}$ \\
\hline LBM $(\mathrm{kg})$ & $49.88 \pm 4.66 a$ & $50.67 \pm 5.78 \mathrm{a}$ & $51.52 \pm 4.72 a$ & $47.64 \pm 2.03 a$ & $53.21 \pm 6.6 \mathrm{la}$ & $47.13 \pm 2.37 a$ & $52.08 \pm 4.92 a$ & $50.43 \pm 3.14 a$ & $47.72 \pm 8.42 a$ & $48.44 \pm 2.8 \mathrm{la}$ & $55.74 \pm 6.56 a$ \\
\hline BFM (kg) & $10.75 \pm 3.82 a$ & $11.63 \pm 6.75 a$ & $9.55 \pm 3.70 \mathrm{a}$ & $9.47 \pm 1.88 \mathrm{a}$ & $14.74 \pm 6.17 \mathrm{a}$ & $5.29 \pm 2.16 a$ & $25.32 \pm 12.80 c$ & $15.21 \pm 3.77 \mathrm{a}$ & $28.12 \pm 22.80 c$ & $9.09 \pm 1.92 a$ & $18.94 \pm 0.06 b$ \\
\hline TBW (litre) & $36.86 \pm 2.76 a$ & $37.19 \pm 3.78 a$ & $37.69 \pm 2.82 a$ & $35.90 \pm 0.85 a$ & $35.80 \pm 1.70 \mathrm{a}$ & $35.90 \pm 2.01 \mathrm{a}$ & $39.34 \pm 3.82 a$ & $39.47 \pm 2.74 a$ & $35.63 \pm 5.0 \mathrm{la}$ & $35.80 \pm 1.70 \mathrm{a}$ & $41.55 \pm 2.33 a$ \\
\hline IF (litre) & $20.26 \pm 1.5 \mathrm{la}$ & $20.56 \pm 2.04 a$ & $20.73 \pm 1.45 a$ & $19.85 \pm 0.35 a$ & $21.25 \pm 2.33 a$ & $19.73 \pm 1.11 \mathrm{a}$ & $21.64 \pm 2.07 a$ & $21.67 \pm 1.43 a$ & $19.60 \pm 2.74 \mathrm{a}$ & $19.75 \pm 0.92 a$ & $22.85 \pm 1.34 a$ \\
\hline EF (litre) & $16.58 \pm 1.24 a$ & $16.58 \pm 2.05 a$ & $16.96 \pm 1.19 a$ & $16.20 \pm 0.28 a$ & $17.35 \pm 1.91 \mathrm{a}$ & $16.17 \pm 0.90 a$ & $17.73 \pm 1.68 \mathrm{a}$ & $17.71 \pm 1.18 \mathrm{a}$ & $16.03 \pm 2.27 a$ & $16.15 \pm 0.78 a$ & $18.70 \pm 1.13 a$ \\
\hline $\begin{array}{l}\text { BP (systolic) } \\
\text { (mm Hg) }\end{array}$ & $123.64 \pm 15.88 \mathrm{a}$ & $1 \mid 2.82 \pm 23.7 \mathrm{Ia}$ & $134.63 \pm 10.85 a$ & $128.00 \pm 11.31 \mathrm{a}$ & $115.00 \pm 12.73 a$ & $113.14 \pm 33.86 \mathrm{a}$ & $114.60 \pm 25.18 \mathrm{a}$ & $1 \mid 4.29 \pm 6.78 \mathrm{a}$ & $120.00 \pm 14.24 a$ & $117.50 \pm 6.36 \mathrm{a}$ & $110.50 \pm 14.85 a$ \\
\hline $\begin{array}{l}\text { BP (diastolic) } \\
(\mathrm{mm} \mathrm{Hg})\end{array}$ & $81.09 \pm 19.94 a$ & $69.12 \pm 16.67 a$ & $75.88 \pm 10.34 a$ & $61.50 \pm 16.26 \mathrm{a}$ & $65.50 \pm 2.12 \mathrm{a}$ & $60.71 \pm 15.00 \mathrm{a}$ & $66.20 \pm 15.19 a$ & $79.57 \pm 7.04 a$ & $67.00 \pm 11.34 a$ & $73.00 \pm 1.41 \mathrm{a}$ & $77.00 \pm 24.04 a$ \\
\hline
\end{tabular}

Values in a row having no letter $(a-d)$ in common are significantly different from each other $(p<0.05)$.

petrol station attendants. With the exception of the drivers and spare parts dealers, majority of the artisans spend an average of 11 hours per day in their workshops. The petrol station attendants on the other hand, spend an average of 14.3 hours with their nozzle.

Analyses of the anthropometric parameters determined in the subjects revealed unsystematic statistically significant differences between the control and the artisans. BMI was higher in drivers, petrol station attendants and welders, but the increase was not statistically significant $(\mathrm{p}=$ 0.512 ). BSA was decreased in spare parts/oil sellers, whereas it increased in the welders $(p<0.05)$. BFMI was significantly increased in the panel beaters, petrol station attendants, upholsterers and welders $(\mathrm{p}<0.05)$, whereas FFMI was decreased in the upholsterers $(\mathrm{p}<0.05)$. While BFM was increased in panel beaters, upholsterers and welders ( $p<0.05)$, no statistical significant differences were observed between control and the artisans in LBM, TBW, IF and EF.

\section{Blood pressure}

The mean blood pressures of the subjects as depicted in Table 2 indicate that the systolic and diastolic blood pressures of the subjects were in the normotensive range. The auto-electricians however had a borderline high systolic blood pressure (134.63 $\pm 10.85 \mathrm{mmHg})$. However, statistical analyses revealed no significant difference in both the systolic and diastolic blood pressures between the control and the artisans ( $\mathrm{p}>0.05)$.

\section{Plasma lipid profiles}

The mean values of the investigated blood lipids in the subjects are depicted in Table 3. With a few exceptions, the mean values of these lipids were within the reference ranges prescribed by the American Heart Association [26]. Total cholesterol was slightly higher in the battery chargers while LDL cholesterol was above the reference range in the battery chargers, drivers and petrol station attendants. When the values of the investigated lipids in the artisans were however compared with the controls, certain patterns emerged. With the exception of the painters, the mean plasma concentrations of total cholesterol were significantly higher in the artisans compared with control subjects $(p<0.001)$. Of the artisans, the battery chargers had the highest plasma total cholesterol $(203.50 \pm 48.51$ $\mathrm{mg} / \mathrm{dl}$ ), followed by the spare parts/oil sellers and drivers respectively. Quantitatively, cholesterol levels of the artisans were between 1.5 and 2.0 times higher than that of the controls. Although there were statistically significant differences in the LDL-cholesterol between control and the artisans, the increases in this parameter exhibited a different pattern compared with total cholesterol. While LDL cholesterol was not significantly different in the painters, upholsterers, spare parts/oil sellers and welders when compared with controls $(\mathrm{p}>0.05)$, values obtained for the auto-mechanics, auto-electricians, drivers, panel beaters, battery chargers and petrol station attendants were significantly higher than controls $(\mathrm{p}<0.001)$. In these groups of artisans, the LDL cholesterol levels were between 1.6 to 2.4 times higher than control subjects. In contrast however, both triglyceride and HDL cholesterol concentrations were not significantly different between 
Table 3: Blood lead and blood lipid profiles of the subjects. Values are mean \pm S.D.

\begin{tabular}{|c|c|c|c|c|c|c|c|c|c|c|c|}
\hline \multicolumn{12}{|c|}{ Subjects } \\
\hline Parameter & Control & Auto-mechanics & $\begin{array}{l}\text { Auto- } \\
\text { electricians }\end{array}$ & Battery chargers & Drivers & $\begin{array}{l}\text { Painters } \\
\text { (Vehicle) }\end{array}$ & Panel beaters & $\begin{array}{l}\text { Petrol station } \\
\text { attendants }\end{array}$ & Upholsterers & $\begin{array}{l}\text { Spare parts/Oil } \\
\text { sellers }\end{array}$ & Welders \\
\hline $\begin{array}{l}\text { Blood lead } \\
(\mu \mathrm{g} / \mathrm{dl})\end{array}$ & $15.78 \pm 2.84 \mathrm{a}$ & $43.98 \pm 10.54 \mathrm{e}$ & $48.90 \pm 19.1 \mathrm{If}$ & $41.13 \pm 11.55 d$ & $40.99 \pm 7.00 \mathrm{~d}$ & $36.10 \pm 9.64 c$ & $35.99 \pm 11.08 c$ & $42.53 \pm 5.90 d$ & $31.61 \pm 7.78 c$ & $35.79 \pm 6.30 c$ & $27.00 \pm 1.05 b$ \\
\hline $\begin{array}{l}\text { Total chol. } \\
(\mathrm{mg} / \mathrm{dl})\end{array}$ & $106.17 \pm 16.74 a$ & $170.42 \pm 43.80 c$ & $166.83 \pm 43.86 b$ & $203.50 \pm 48.5 \mathrm{le}$ & $184.88 \pm 64.59 \mathrm{~d}$ & $127.69 \pm 19.34 a$ & $|76.78 \pm 52.8| \mathrm{c}$ & $157.29 \pm 27.94 b$ & $152.70 \pm 61.10 \mathrm{~b}$ & $187.08 \pm 57.88 d$ & $157.96 \pm 87.17 \mathrm{~b}$ \\
\hline $\begin{array}{l}\text { Triglyceride } \\
(\mathrm{mg} / \mathrm{dl})\end{array}$ & $64.17 \pm 30.36 \mathrm{a}$ & $77.29 \pm 34.65 a$ & $66.90 \pm 22.57 a$ & $75.29 \pm 18.50 \mathrm{a}$ & $84.19 \pm 38.72 a$ & $104.85 \pm 35.21 \mathrm{a}$ & $65.47 \pm 29.15 a$ & $60.58 \pm 21.02 \mathrm{a}$ & $81.61 \pm 71.83 a$ & $104.50 \pm 19.81 \mathrm{la}$ & $69.68 \pm 34.16 a$ \\
\hline $\begin{array}{l}\text { HDL chol. } \\
\text { (mg/dl) }\end{array}$ & $50.65 \pm 6.96 a$ & $45.01 \pm 16.1 \mathrm{la}$ & $51.32 \pm 14.04 a$ & $40.56 \pm 2.55 \mathrm{a}$ & $39.78 \pm 19.80 \mathrm{a}$ & $49.58 \pm 11.54 \mathrm{a}$ & $41.49 \pm 17.21 \mathrm{a}$ & $40.55 \pm 15.42 a$ & $27.68 \pm 10.43 a$ & $52.26 \pm 5.37 a$ & $73.03 \pm 14.17 b$ \\
\hline $\begin{array}{l}\text { LDL chol. } \\
(\mathrm{mg} / \mathrm{dl})\end{array}$ & $62.96 \pm 24.68 \mathrm{a}$ & $99.93 \pm 33.67 b$ & $101.12 \pm 42.91 \mathrm{~b}$ & $147.00 \pm 49.50 c$ & $133.85 \pm 81.69 b$ & $90.72 \pm 35.70 \mathrm{a}$ & $114.50 \pm 30.52 b$ & $148.52 \pm 29.62 c$ & $82.22 \pm 59.75 a$ & $69.54 \pm 3.48 \mathrm{a}$ & $83.39 \pm 44.29 a$ \\
\hline $\begin{array}{l}\text { Total chol./ } \\
\text { HDL chol. }\end{array}$ & $2.15 \pm 0.55 \mathrm{a}$ & $4.49 \pm 3.08 \mathrm{~b}$ & $3.46 \pm 1.29 a$ & $4.99 \pm 0.88 \mathrm{~b}$ & $5.77 \pm 4.49 b$ & $2.65 \pm 0.54 a$ & $4.70 \pm 2.10 b$ & $4.28 \pm 1.33 a$ & $5.48 \pm 0.63 b$ & $3.66 \pm 1.48 \mathrm{a}$ & $2.09 \pm 0.79 a$ \\
\hline $\begin{array}{l}\text { LDL chol./ } \\
\text { HDL chol. }\end{array}$ & $1.25 \pm 0.47 \mathrm{a}$ & $2.6 \mathrm{I} \pm 1.49 \mathrm{~b}$ & $2.15 \pm 1.18 \mathrm{a}$ & $3.60 \pm 1.00 c$ & $4.42 \pm 4.26 \mathrm{e}$ & $1.91 \pm 0.82 \mathrm{a}$ & $3.27 \pm 1.7 \mathrm{lb}$ & $4.00 \pm 1.11 d$ & $3.20 \pm 2.03 b$ & $1.33 \pm 0.07 \mathrm{a}$ & $1.11 \pm 0.39 \mathrm{a}$ \\
\hline
\end{tabular}

Values in a row having no letter $(a-f)$ in common are significantly different from each other $(p<0.05)$.

control and the artisans ( $\mathrm{p}>0.05)$, although the upholsterers tended to have lower HDL cholesterol concentrations when compared with others.

The ratios of the lipids, total cholesterol/HDL cholesterol on one hand, and LDL cholesterol/HDL cholesterol on the other hand, are also depicted in Table 3. There were no statistical significant differences between the control and the artisans in total cholesterol/HDL cholesterol ratios (p $>0.05)$, although there was a tendency towards higher ratios in the artisans. In contrast however, LDL cholesterol/HDL cholesterol ratios were significantly increased in the artisans when compared with the control subjects $(\mathrm{p}<0.001)$. Of the artisans, the highest ratio was observed in the drivers $(4.42 \pm 4.23)$, followed closely by the petrol station attendants with $4.00 \pm 1.10$.

\section{Blood lead concentrations}

The mean blood lead concentrations in the subjects are also depicted in Table 3. Lead levels in the blood of the artisans were significantly higher than that of control ( $\mathrm{p}<$ 0.001 ). Of the artisans, the auto-electricians had the highest blood lead level of $48.90 \pm 19.11 \mu \mathrm{g} / \mathrm{dl}$, a value which was 3 times higher than that of control subjects.

\section{Correlations between blood lead and anthropometric parameters, and blood lead and investigated lipids}

There was no significant correlation between blood lead levels and any of the anthropometric parameters ( $\mathrm{p}>$ 0.05) (Data not shown). However, a positive significant correlation was observed between blood lead and total cholesterol $\left(\mathrm{r}=0.372 ; \mathrm{p}=3.0 \times 10^{-5}\right)$ and blood lead and LDL cholesterol $(\mathrm{r}=0.283 ; \mathrm{p}=0.001)$. We also analysed our data to see whether any correlation existed among the anthropometric parameters on one hand and anthropometric parameters and investigated lipids on the other hand. The following were observed:
1. A significant positive correlation between age and systolic blood pressure $\left(r=0.325 ; \mathrm{p}=3.0 \times 10^{-4}\right)$.

2. A significant positive correlation between age and diastolic blood pressure $(\mathrm{r}=0.232 ; \mathrm{p}=0.007)$.

3. A significant positive correlation between age and BMI $\left(\mathrm{r}=0.449 ; \mathrm{p}=1 \times 10^{-5}\right)$.

4. A significant positive correlation between weight and triglyceride $(\mathrm{r}=0.275 ; \mathrm{p}=0.006)$.

5. A significant positive correlation between age and weight $\left(\mathrm{r}=0.418 ; \mathrm{p}=5 \times 10^{-5}\right)$.

6. A significant positive correlation between BMI and triglyceride $\left(\mathrm{r}=0.354 ; \mathrm{p}=6 \times 10^{-4}\right)$.

7. A significant positive correlation between BSA and LDL cholesterol $(r=0.202 ; \mathrm{p}=0.035)$.

8. A significant positive correlation between age and BSA $\left(\mathrm{r}=0.390 ; \mathrm{p}=1 \times 10^{-4}\right)$.

9. A significant positive correlation between BMI and systolic blood pressure $\left(\mathrm{r}=0.371 ; \mathrm{p}=7 \times 10^{-4}\right)$.

10. A significant positive correlation between BMI and diastolic blood pressure $\left(\mathrm{r}=0.424 ; \mathrm{p}=1 \times 10^{-4}\right)$.

\section{Discussion}

During the past decade, a vast amount of evidence has confirmed that lipid and lipoprotein abnormalities play a major role in the pathogenesis and progression of atherosclerosis and cardiovascular diseases [23-27]. These chronic degenerative disorders have become a growing health problem worldwide. 
In African populations, dyslipidemia as a risk factor for cardiovascular disease and increasing incidents of death due to cardiovascular disease in both urbanised and underdeveloped rural countries have been reported [34]. There is also increasing evidence that environmental factors contribute to this dyslipidemia [35]. In this present study, we evaluated the distribution of some blood lipids in a population of artisans who are occupationally exposed to lead, an occupational and environmental pollutant. We found that majority of the artisans had HDL cholesterol and triglyceride levels not significantly different from controls. On the contrary, total cholesterol levels in the artisans were between 1.5 and 2.0 times higher than controls. In addition, LDL cholesterol in some of the artisans was considerably higher when compared with controls. To our knowledge, the distribution of blood lipids in artisans in Nigeria has not been reported in the literature. We were compelled to compare our data with the guidelines of risk factors for cardiovascular disease given by the American Heart Association [26]. According to these guidelines, blood pressure $<130 / 85 \mathrm{mmHg}$; total cholesterol $<200 \mathrm{mg} / \mathrm{dl}$; triglycerides $<200 \mathrm{mg} / \mathrm{dl}$; HDL $>$ $40 \mathrm{mg} / \mathrm{dl}$ and LDL $<130 \mathrm{mg} / \mathrm{dl}$, are favourable risk factors. In addition, certain lipid ratios like total cholesterol/HDL cholesterol and the LDL cholesterol/HDL cholesterol ratio also correlate with cardiovascular disease. The recommended ratios for the two are $\leq 3.5$ [26]. Indications from this comparison are that while the HDL cholesterol and triglyceride concentrations of both the controls and artisans were within the acceptable range prescribed by the American Heart Association, the battery chargers with total cholesterol of $203.50 \pm 48.51 \mathrm{mg} / \mathrm{dl}$ and LDL cholesterol of $147.00 \pm 49.50 \mathrm{mg} / \mathrm{dl}$, drivers with LDL cholesterol of $133.85 \pm 81.69 \mathrm{mg} / \mathrm{dl}$, and petrol station attendants with LDL cholesterol of $148.52 \pm 29.62$ $\mathrm{mg} / \mathrm{dl}$, seem to have unfavourable risk profiles for cardiovascular disease when compared with other artisans and control. Furthermore, the LDL/HDL ratio of the artisans indicate that battery chargers, petrol station attendants and drivers seem to have a greater risk of cardiovascular disease when compared with other artisans and controls. As regards total cholesterol/HDL cholesterol ratio, the auto-mechanics, battery chargers, drivers, panel beaters, petrol station attendants, spare parts/oil sellers and upholsterers, seem to be at risk of cardiovascular disease. Although cholesterol levels are lower in African population when compared with their American counterparts $[36,37]$, the findings of the present investigation indicate that exposure to lead alters the metabolism of cholesterol and thus increases the risk of cardiovascular disease and atherosclerosis in lead-exposed subjects. Although correlations do not imply causality, the observation of a positive relationship between lead and total cholesterol on one hand, and lead and LDL cholesterol on the other hand, seems to support these experimental findings.
HDL and LDL are two of the four main groups of plasma lipoproteins that are involved in lipid metabolism and the exchange of cholesterol, cholesterol ester and triglycerides between tissues [38-40]. Numerous population studies have shown an inverse correlation between plasma HDL levels and risk of cardiovascular disease, implying that factors associated with HDL protect against atherosclerosis. Some of these factors appear to have anti-oxidant and anti-inflammatory effects which may obviate processes that initiate atherogenesis $[41,42]$. Epidemiological studies have also shown that elevated concentrations of total or LDL cholesterol in the blood are powerful risk factors for coronary disease [43]. Most extra-hepatic tissues, although having a requirement for cholesterol, have low activity of the cholesterol biosynthetic pathway. Their cholesterol requirements are supplied by LDL, which is internalised by receptor-mediated endocytosis. A major function of HDL cholesterol is to enhance reverse cholesterol transport by scavenging excess cholesterol from peripheral tissues followed by esterification through lecithin:cholesterol acyltransferase and delivering it to the liver and steroidogenic organs for subsequent synthesis of bile acids and lipoproteins and eventual elimination from the body $[44,45]$. This role of HDL has been shown to be responsible for its atheroprotective properties. HDL cholesterol also regulates the exchange of proteins and lipids between various lipoproteins [46]. In addition, HDL provides the protein components required to activate lipoprotein lipase which releases fatty acids that can be oxidised by the $\beta$-oxidation pathway to release energy [3840]. Most importantly, HDL can inhibit oxidation of LDL as well as the atherogenic effects of oxidised LDL by virtue of its antioxidant property [45]. The observation of increased total plasma cholesterol and LDL cholesterol levels, and normal HDL cholesterol levels in the artisans in this study suggests that reverse cholesterol transport in these artisans was not affected by lead exposure, rather cholesterol synthesis and transport to the peripheral tissues might be affected. It is possible that lead increases the activity of 3-hydroxy-3-methylglutaryl coenzyme A (HMG $\mathrm{CoA}$ ) reductase (the rate-limiting enzyme in cholesterol biosynthesis) and reduces the number/affinity of LDL receptors for cholesterol. Further studies that we are pursuing in this laboratory are addressing this hypothesis.

Exposure to lead has been shown to be a significant risk factor for the development of hypertension $[47,48]$ and this is supported by experimental animal studies in several species as well as epidemiological studies of blood pressure in relation to blood lead levels [47-49]. Most, but not all, of the studies have demonstrated that blood lead increases from 10 to $25 \mu \mathrm{g} / \mathrm{dl}$ are associated with systolic and diastolic blood pressure increases of $1.4-8 \mathrm{mmHg}$ and 1.2-4 $\mathrm{mmHg}$, respectively [48]. Mean blood lead levels observed in the artisans in this study were between 2.5 
and 3.0 times higher than control subjects. Even though job experience indicated that lead exposure has been going on in these artisans for 4 to 26 years, only the autoelectricians had a borderline high systolic blood pressure as prescribed by the American Heart Association. It remains to be established in these artisans the threshold value of blood lead that might be associated with increased blood pressure.

In addition to blood lipids, other factors such as age, physical activity, genetics, body composition, alcohol intake, tobacco use and body fat distribution, contribute significantly to risk of cardiovascular disease $[26,50]$. All the subjects who participated in this study were nonsmokers and all consume cassava-based meal as their carbohydrate source. Alcohol intake was limited to only six of the auto-mechanics who consume 1 bottle of beer per day. By virtue of the demands of their occupations, most of the artisans are physically active and this might account for the normal levels of HDL cholesterol observed in them [35]. The anthropometric parameters measured in the artisans did not reveal any statistically significant difference between the control subjects and artisans, thus suggesting that these factors may not play any significant role in the dyslipidemia observed in these artisans.

The increased plasma cholesterol levels observed in these artisans raises a few questions. Since erythrocyte cholesterol reflects plasma cholesterol, it might be interesting to investigate cholesterol levels in the erythrocytes in lead exposure and how this affects cholesterol:phospholipid ratio in both plasma and erythrocytes. The consequences of these alterations might probably explain alterations observed in cation fluxes in the erythrocyte membrane in lead exposure. Studies going on at present in this laboratory are directed towards addressing these questions.

\section{Acknowledgements}

The authors are grateful to the heads of the two mechanic workshops and the other subjects in the workshops who participated in the study.

Our thanks are also due to the medical and nursing teams of University of Agriculture Health Centre, Abeokuta, Nigeria, for their support in this study. The technical assistance of Mrs. J. O. Adebawa is also highly appreciated.

\section{References}

I. Adonaylo $\mathrm{VN}$, Oteiza $\mathrm{PI}: \mathbf{P b}^{2+}$ promotes lipid oxidation and alterations in membrane physical properties. Toxicol 1999, 132:19-32.

2. Bhattacharjee CR, Dey S, Goswami P: Protective role of ascorbic acid against lead toxicity in blood of albino mice as revealed by metal uptake, lipid profiles and ultrastructural features of erythrocytes. Bull Environ Contam Toxicol 2003, 70:I I89-I I 96.

3. Deng W, Poretz RD: Lead exposure affects levels of galactolipid metabolic enzymes in the developing rat brain. Toxicol Appl Pharmacol 200I, I 72:98-107.

4. Ito Y, Niiya Y, Kurita H, Shima S, Sarai S: Serum lipid peroxide dismutase activity in workers with occupational exposure to lead. Arch Occup Environ Health 1985, 56: I 19-1 27.
5. Osterode W, Ulberth F: Increased concentration of arachidonic acid in erythrocyte membranes in chronically lead-exposed men. J Toxicol Environ Health Part A 2000, 59:87-95.

6. Skoczynska A, Smolik R, Jelen M: Lipid abnormalities in rats given small doses of lead. Arch Toxicol 1993, 63:200-204.

7. Quinlan GJ, Halliwell B, Moorehouse CP, Gutteridge MC: Action of lead(II) and aluminium (III) ions on iron-stimulated lipid peroxidation in liposomes, erythrocytes and rat liver microsomal fractions. Biochem Biophys Acta 1988, 962: I96-200.

8. Rivarov SR, Benov LC, Benchev IC: The effect of lead on hemoglobin-catalyzed lipid peroxidation. Biochim Biophys Acta I98I, 664:453-459.

9. Oteiza PI, Verstraeten SV, Adonaylo VN: Oxidative damage induced by metals without redox capacity in biological systems. Cienc Cult 1995, 47:330-335.

10. Donaldson WE, Knowles SO: Is lead toxicosis a reflection of altered fatty acid composition of membranes? Comp Biochem Physiol 1993, I04C:377-379.

II. Lawton LJ, Donaldson WE: Lead-induced tissue fatty acid alterations and lipid peroxidation. Biol Trace Elem Res I99I, 28:83-97.

12. Ademuyiwa O, Arowolo T, Ojo DA, Odukoya OO, Yusuf AA, Akinhanmi TF: Lead levels in blood and urine of some residents of Abeokuta, Nigeria. Trace Elem Electro 2002, 19:63-69.

13. Ademuyiwa O, Ugbaja RN, Ojo DA, Owoigbe AO, Adeokun SE: Reversal of aminolevulinic acid dehydratase (ALAD) inhibition and reduction of erythrocyte protoporphyrin levels by vitamin $\mathbf{C}$ in occupational lead exposure in Abeokuta, Nigeria. Environ Toxicol Pharmacol 2005, 20(3):404-4I I.

14. Dosumu O, Onunkwor B, Odukoya O, Arowolo T, Ademuyiwa O: Biomarkers of lead exposure in auto-mechanics in Abeokuta, Nigeria. Trace Elem Electro 2005, 22(3): I85-191.

15. Nriagu JO, Blankson ML, Ocran K: Childhood lead poisoning in Africa: A growing public health problem. Sci Total Environ 1996, | 81:93-100.

16. Onunkwor B, Dosumu O, Odukoya OO, Arowolo T, Ademuyiwa O: Biomarkers of lead exposure in petrol station attendants and auto-mechanics in Abeokuta, Nigeria: effects of 2-week ascorbic acid supplementation. Environ Toxicol Pharmacol 2004, I 7:169-176.

17. Canfield RL, Henderson CR Jr, Cory-Slechta DA, Cox C, Jusko TA, Lanphear BP: Intellectual impairment in children with blood lead concentrations below $10 \mu \mathrm{g}$ per deciliter. $N$ Engl J Med 2003, 348( (16): I $517-1526$.

18. EPA: Air quality criteria for lead (vols. I-IV EPA-600/8-83/ 02aF). US Environmental Protection Agency, Washington DC; 1986.

19. Goyer RA: Lead toxicity: current concerns. Environ Health Perspect 1993, 100:177-187.

20. Meyer I, Heinrich J, Trekpa M: The effect of lead in tap water on blood lead in children in a smelter town. Sci Total Environ 1998, 209:255-27I.

21. Pirkle J, Brody D, Gunter E: The decline in blood lead levels in the United States. The National Health and Nutrition Examination Surveys (NHANES). J Am Med Assoc 1994, 272:284-291.

22. Ponka A: Lead in the ambient air and blood of children in Helsinki. Sci Total Environ 1998, 2 I 9: I-5.

23. Chrysohoou C, Panagiotakos DB, Pitsavos C, Kosma K, Barbetseas J, Karagiorga M, Ladi I, Stefanadis C: Distribution of serum lipids and lipoproteins in patients with beta thalassaemia major; an epidemiological study in young adults from Greece. Lipids Health Dis 2004, 3:3.

24. Ginsberg HN: Lipoprorein metabolism and its relationship to atherosclerosis. Med Clin North Am 1994, 78: I-20.

25. Glew RH, Williams M, Conn CA, Cadena SM, Crossey M, Okolo SN: Cardiovascular disease risk factors and diet of fulani pastorialists of northern Nigeria. Am J Clin Nutr 200 I, 74:730-736.

26. Glew RH, Kassam HA, Bhanji RA, Okorodudu A, Vanderjagt DJ: Serum lipid profiles and risk of cardiovascular disease in three different male populations in northern Nigeria. J Health Popul Nutr 2002, 20:166-I74.

27. Gotto AM Jr: Lipid and lipoprotein disorder. In Primer in Preventive Cardiology Edited by: Pearson TA, Criqui MH, Luepker RV, Oberman A, Wilson M. Dallas Tex; American Heart Association; 1994: 107-129.

28. Vanltallie TB, Yan M-U, Heymsfeld SB, Funk RC, Boileau RA: Height normalised indices of the body's fat free mass and fat 
mass:potentially useful indicators of nutritional status. Am J Clin Nutri 1990, 52(6):953-959.

29. James WPT: Research on obesity. Her Majesty Stationery Office, London; 1976.

30. Hume R, Weyers : Relationship between total body water and surface area in normal and obese subjects. J Clin Pathol I97I, 24:234-238.

31. Famodu AA, Osilesi O, Makinde YO, Osonuga OA: Blood pressure and blood lipid levels among vegetarian, semi-vegetarian and non-vegetarian native Africans. Clin Biochem 1998, 3 1 7:545-549.

32. Gidez LI, Miller G], Burstein M, Slagle S, Eder HA: Separation and quantitation of subclasses of human plasma high density lipoproteins by a simple precipitation procedure. J Lipid Res 1982, 23:1206-1223.

33. Sachs L: Angewandte Statistik. Springer Verlag, Berlin; 1983.

34. van der Sande MA, Inskip HM, Jaiteh KO, Maine NP, Walraven GE, Hall AJ, McAdam KP: Changing causes of death in the West African town of Banjul, 1942-1997. Bull World Health Organ 200I, 79:|33-|4|.

35. Aguilar-Salinas CA, Olaiz G, Valles V, Torres JMR, Pérez FJG, Rull JA, Rojas R, Franco A, Sepulveda J: High prevalence of low HDL cholesterol concentrations and mixed hyperlipidemia in a Mexican nationwide survey. J Lipid Res 200I, 42: 1298-I 307.

36. Brotons C, Ribera A, Perich RM, Abrodos D, Magana P, Pablo S, Teradas D, Fernadez F, Permanyer G: Worldwide distribution of blood lipids and lipoproteins in childhood and adolescence: a review study. Atherosclerosis 1997, 139: I-9.

37. Bansal D, Bhatti HS, Sehgal R: Role of cholesterol in parasitic infections. Lipids Health Dis 2005, 4:10.

38. Gordon DJ, Rifkind BM: High-density lipoprotein: the clinica implications of recent studies. N Eng J Med 1989, $321(19):|3||-| 3 \mid 6$

39. Sviridiv D: Intracellular cholesterol trafficking. Histol Histopathol 1999, 14:305-319.

40. McNamara DJ: Dietary fatty acids, lipoproteins, and cardiovascular disease. Adv Food Nutr Res 1999, 36:253.

4I. Navab M, Berliner JA, Watson AD, Hama SY, Territo MC, Lusis AJ, Shih DM, Van Lenten BJ, Frank JS, Demer LL, Edwards PA, Fogelman AM: The Yin and Yang of oxidation in the development of the fatty streak. A review based on the 1994 George Lyman Duff Memorial Lecture. Arterioscler Thromb Vasc Biol 1996, 16:83 I-842.

42. Oram JF, Lawn RM: ABCAI: the gatekeeper for eliminating excess tissue cholesterol. J Lipid Res 200 I, 42:1 I73-I I79.

43. Law MR: Lowering heart disease risk with cholesterol reduction:evidence from observational studies and clinical trials. Eur Heart J Suppl 1999, I:S3-S8.

44. Stein O, Stein Y: Atheroprotective mechanisms of HDL. Atherosclerosis 1999, 144:285-303.

45. Das DK: Cardioprotection with high density lipoproteins. Fact or friction? Circ Res 2003, 92:258-260.

46. Jacques PF, Bostom AG, Williams RR, Ellison RC, Eckfeldt JH, Rosenberg IH, Selhub J, Rozen R: Relation between folate status, a common mutation in methylene tetrahydrofolate reductase and plasma homocysteine concentrations. Circulation 1996, 93:7-9.

47. Tsao DA, Yu HS, Cheng JT, Ho CK, Chang HR: The change of beta adrenergic system in lead-induced hypertension. Toxicol Appl Pharmacol 2000, 164:127-133.

48. Hertz-Picciotto I, Croft J: Review of the relation between blood lead and blood pressure. Epidemiol Rev 1993, 15:352-373.

49. Schwartz J: Lead, blood pressure and cardiovascular disease in men. Arch Environ Health 1995, 50:31-37.

50. Brochu M, Poehlman ET, Savage P, Ross S, Ades PA: Coronary risk profiles in men with coronary artery disease: effects of body composition, fat distribution, age and fitness. Coron Artery Dis 2000 , II:137-144
Publish with Bio Med Central and every scientist can read your work free of charge

"BioMed Central will be the most significant development for disseminating the results of biomedical research in our lifetime. "

Sir Paul Nurse, Cancer Research UK

Your research papers will be:

- available free of charge to the entire biomedical community

- peer reviewed and published immediately upon acceptance

- cited in PubMed and archived on PubMed Central

- yours - you keep the copyright
BioMedcentral 